\title{
PENINGKATAN MUTU KUALITAS AIR UNTUK PEMBUDIDAYA IKAN AIR TAWAR DI DESA GEGERUNG KABUPATEN LOMBOK BARAT
}

\author{
Andre Rachmat Scabra*), Dewi Nur'aeni Setyowati \\ Program Studi Budidaya Perairan Universitas Mataram \\ Jalan Pendidikan Nomor 37, Mataram \\ *alamat korespondensi: andrescabra@unram.ac.id
}

\begin{abstract}
ABSTRAK
Desa Gegerung, Kecamatan Lingsar, Kabupaten Lombok Barat, merupakan salah satu desa yang memiliki potensi untuk pengembangan perikanan air tawar. Hal tersebut dapat dilihat dari cukup berlimpahnya sumber air pada kawasan Desa Gegerung. Kegiatan budidaya ikan yang telah berlangsung pada kawasan Desa Gegerung masih belum berjalan dengan optimal. Hal tersebut disebabkan oleh beberapa hal antara lain teknologi budidaya yang masih tradisional. Kesadaran masyarakat akan kebersihan juga masih kurang yang ditandai dengan masih banyaknya masyarakat yang membuang sampah di sungai. Kualitas air merupakan salah satu faktor penting yang mendukung keberhasilan usaha budidaya perikanan. anajemen kualitas air yang baik merupakan upaya yang harus dilakukan untuk dapat meningkatkan pertumbuhan atau produksi ikan. Kegiatan pengabdian kepada masyarakat ini bertujuan untuk dapat mememecahkan permasalahan dalam kegiatan budidaya melalui beberapa tahapan, antara lain melakukan sosialisasi tentang pentingnya menjaga kebersihan lingkungan, Memberi penyuluhan tentang hubungan kualitas air dengan kegiatan budidaya ikan, dan teknologi peningkatkan produksi ikan air tawar. Kegiatan pengabdian kepada masyarakat ini berhasil meningkatkan pengetahuan masyarakat tentang pentingnya menjaga kualitas air pada kegiatan budidaya ikan serta bagaimana metode-metode yang dapat dilakukan guna menjaga kualitas air pada kolam budidaya ikan.
\end{abstract}

Kata kunci: kualitas air, budidaya ikan air tawar, desa gegerung

\section{PENDAHULUAN}

Desa Gegerung, Kecamatan Lingsar, Kabupaten Lombok Barat, merupakan salah satu desa yang memiliki potensi untuk pengembangan perikanan air tawar.
Struktur perekonomian di desa tersebut didominasi oleh kegiatan agronomi. Hal tersebut disebabkan oleh kontur wilayahnya yang terdiri dari pengunungan dan persawahan. Kondisi tersebut didukung oleh sumber daya alam nya yang cukup 
memadai, yaitu curah hujan yang relatif tinggi. Pada kawasan desa tersebut, terdapat sebuah sungai yang cukup terjaga kondisinya sehingga penggunaan airnya dapat dimanfaatkan sebagai irigasi persawahan dan kegiatan pembudidayaan ikan.

Keberadaan air yang cukup melimpah pada kawasan Desa Gegerung sudah mulai dimanfaatkan oeh masyarakat sekitar untuk kegiatan budidaya ikan. Kegiatan pertanian masih menjadi kegiatan utama, namun beberapa kelompok mulai merambah pada aspek yang lain yaitu budidaya perikanan tawar. Hal tersebut disebaban oleh penghasilan ekonomi yang didapat melalui usaha budidaya ikan adalah lebih tinggi dibandingkan dengan usaha pertanian dengan asumsi luasan lahan yang sama. Dimulainya kegiatan budidaya ikan pada desa tersebut lantas menjadi pemicu mulai maraknya kegiatan budidaya.

Kegiatan budidaya ikan yang telah berlangsung pada kawasan Desa Gegerung masih belum berjalan dengan optimal. Hal tersebut disebabkan oleh beberapa hal antara lain teknologi budidaya yang masih tradisional. Kesadaran masyarakat akan kebersihan juga masih kurang yang ditandai dengan masih banyaknya masyarakat yang membuang sampah di sungai. Aktifitas pembuangan sampah tersebut berdampak terhadap kualitas air pada sungai menjadi kurang baik. Selain itu, pemasaran hasil budidaya perikanan juga belum terserap dengan baik. Berbagai hal tersebut mengindikasikan bahwa potensi perikanan yang mulai berkembang pada kawasan desa tersebut masih sangat bisa untuk ditingkatkan.

Kualitas air merupakan salah satu faktor penting yang mendukung keberhasilan usaha budidaya perikanan. Air merupakan media utama huntuk kehidupan dan pertumbuhan ikan serta organisme yang hidup di dalamnya. Effendi (2003) menyatakan bahwa ikan dapat hidup dengan baik pada media budidaya yang sesuai dengan kebutuhannya. Pada kondisi yang optimal, ikan dapat tumbuh dengan maksimal. Pada kondisi yang kurang optmal, ikan lebih banyak beradaptasi sehingga pertumbuhannya tidak maksimal. Affandi dan Tang (2002) menyatakan bahwa dalam rangka meyesuaikan diri dengan lingkungan, ikan memiliki nilai toleransi dan resistensi terhadap perubahan lingkungan pada kisaran tertentu.

Manajemen kualitas air merupakan suatu upaya yang dapat ditempuh untuk meningkatkan produktifitas kegiatan budidaya ikan. Kualitas air dikatakan baik apabila parameter fisik, kimia maupun biologi 
air tersebut sesuai dengan yang dibutuhkan oleh organisme yang dipelihara. Parameter fisik kualitas air antara lain: suhu, kedalaman, kecerahan, TDS, TSS, dll. Parameter kimia kualitas air antara lain: salinitas, oksigen terlarut, BOD, COD, dll. Parameter biologi kualitas air antara lain: kesuburan, kelimpahan plankton, dll. Pemahaman tentang kepentingan menjaga kualitas air merupakan issue utama dalam pelaksanaan kegiatan pengabdian kepada masyarkat di Desa Gegerung ini. Dengan meningkatnya pemahaman masyarakat tersebut, diharapkan nilai budidaya ikan yang dilakukan oleh masyarakat dapat meningkat.

\section{METODE KEGIATAN}

Kegiatan pengabdian kepada masyarakat dilakukan melalui berbagai kegiatan yang tersusun secara terstruktur, antara lain

1. Melakukan survei lokasi dan pendataan tentang pesebaran kelompok budidaya ikan air tawar.

Survei dilakukan untuk mengetahui gambaran umum keadaan lokasi agar tim pengabdian dapat menyesuaikan materi yang diberikan. Pemberian materi yang tepat sasaran diharapkan dapat meningkatkan taraf keberhasilan dari kegiatan pengabdian kepada masyarakat ini. Melalui kegiatan survei ini, tim pelaksana kegiatan pengabdian kepada masyarakat juga melakukan pendekatan secara personal dengan masyarakat. Ikatan personal yang terbentuk diharapkan dapat menunjang keberhasilan kegiatan berdasarkan asas saling keterbukaan dan kepercayaan.

2. Membuat materi penyuluhan yang mudah dimengerti dan diaplikasikan oleh masyarakat sesuai dengan kondisi alam dan latar belakang masyarakat.

Materi penyuluhan dibuat berdasarkan kaidah ilmiah pergurua tinggi yang disusun secara sederhana agar dapat dimengerti dengan mudah oleh masyarakat. Kegiatan survei yang ditelah dilakukan merupakan acuan bentuk materi yang akan disampaikan.

3. Melakukan penyuluhan yang ditindaklanjuti dengan pendampingan usaha budidaya.

Penyuluhan diawali dengan diskusi ringan tentang beragai persoalan yang dihadapi oleh masyarakat dalam kegiatannya membudidayakan ikan. Tim 
kegiatan PKM kemudian menjawab pertanyaan secara sederhana, kemudian menyampaikan materi inti yang telah dipersiapkan sebelumnya.

\section{HASIL DAN PEMBAHASAN}

Permasalahan yang dihadapi masyarakat dalam usaha pembudidaya ikan air tawar di Desa Gegerung terjadi akibat kurangnya pemahaman keilmuan masyarakat dalam bidang tersebut. Beberapa yang terlihat cukup vital adalah kondisi sumber air yang digunakan yang masih belum dapat dikelola dengan baik. Selain itu, informasi tentang teknologi budidaya ikan konvensional juga masih belum sampai kepada masyarakat. Hal tersebut kemudian menjadi acuan dalam pelaksanaan kegiatan ini yang kemudian dituangkan sebagai kegiatan yang akan dilaksanakan dan diharapkan dapat menjadi solusi dalam pemecahan masalah yang dihadapi, antara lain;
1. Mensosialisasikan pentingnya menjaga kebersihan lingkungan

2. Memberi penyuluhan tentang hubungan kualitas air dengan kegiatan budidaya ikan

3. Meningkatkan hasil produksi ikan air tawar.

Kualitas air sebagai media budidaya ikan dapat dikatakan baik berdasarkan tiga kelompok parameter utama, yaitu parameter fisika, kimia dan biologi. Apabila ketiga faktor tersebut baik, maka air yang digunakan untuk budidaya ikan dapat menunjang kehidupan organisme yang dipelihara. Parameter fisika yang dimaksud adalah: suhu, kedalaman, kecerahan, TDS, TSS, dll. Parameter kimia adalah: salinitas, oksigen terlarut, BOD, COD, dll. Parameter biologi adalah : kesuburan, kelimpahan plankton, dll. Melalui kegiatan pengabdian kepada masyarakat (Gambar 1), ketiga kelompok parameter kualitas air tersebut menjadi bahan diskusi yang disampaikan. 


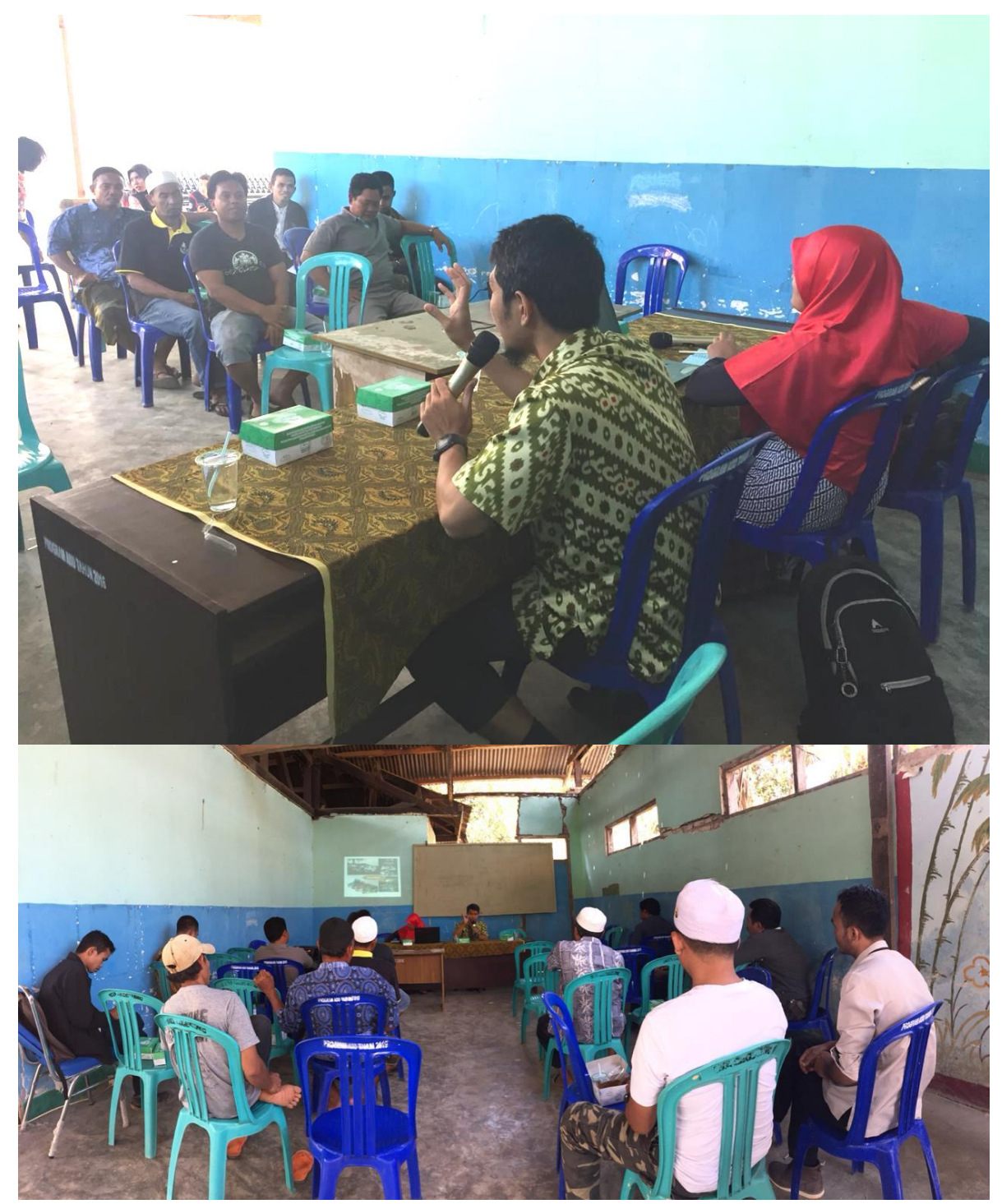

Gambar 1. Penyampaian materi dan diskusi dengan masyarakat.

Suhu berpengaruh terhadap metabolisme organisme air, termasuk ikan. Penelitian yang dilakukan Scabra (2015) menyatakan bahwa faktor suhu yang tidak ideal dapat menyebabkan kematian bibit ikan sidat fase glass eel. Oleh karena itu, dalam pemeliharaan skala laboratorium perlu dilakukan penjagaan suhu agar tetap stabil dan tidak terjadi fluktuasi. Salah satu upaya yang bisa ditempuh adalah denga menggunakan pemanas ubatan (water heater). Untuk produksi skala lapang, penjagaan suhu dapat dilakukan dengan meningkatkan kapasitas daya tampung air. Fluktuasi nilai suhu pada perairan dapat berbandig lurus dengan kapasitas volume air kolam tersebut. Harianto (2014) juga memberikan pendapat tentang suhu pada air, bahwa peningkatan suhu hingga batas maksimal toleransi akan diringi dengan 
terjadinya peningkatan laju yang berdampak terhadap terjadinya metabolisme. Jika metabolisme ikan peningkatan derajat kelangsungan berjalan dengan baik, maka ikan akan hidup dan pertumbuhan ikan.

mampu mencapai titik homeostasis

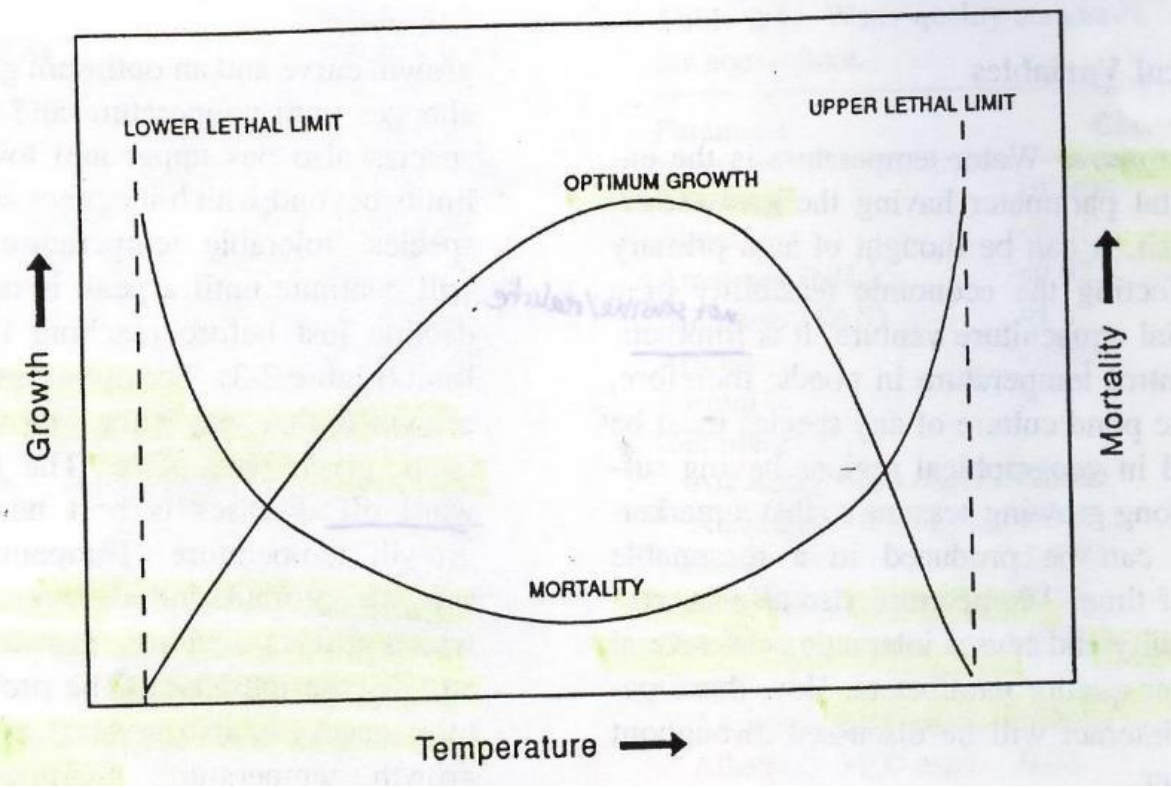

Gambar 2. Hubungan suhu dengan pertumbuhan ikan Boyd (1982)

Oksigen dibutuhkan oleh ikan Proses tersebut dijelaskan melalui untuk berbagai kebutuhan di dalam Gambar 3. Dalam proses penyebaran tubuhnya, antara lain dalam nutrisi, oksigen merupakan pengikat metabolisme dan sebagai pembawa asam-asam amino yang telah diserap nutrisi di dalam aliran darah. Dalam pada dinding usus untuk kemudian proses metabolisme, oksigen berperan disalurkan melalui aliran darah ke dalam membantu oksidasi bahan seluruh tubuh. Keberadaan oksigen buangan dan pembakaran makanan pada media bisa menjadi faktor untuk menghasilkan energi. Net pembatas yang keberadaanya energy yang telah melalui proses sangatlah vital. Kekurangan oksigen pencernaan, baru bisa digunakan pada media pemeliharaan dapat sebagai energi metabolisme basal berdampak terhadap hilangnya nafsu bergantung pada keberadaan oksigen. makan pada ikan. 


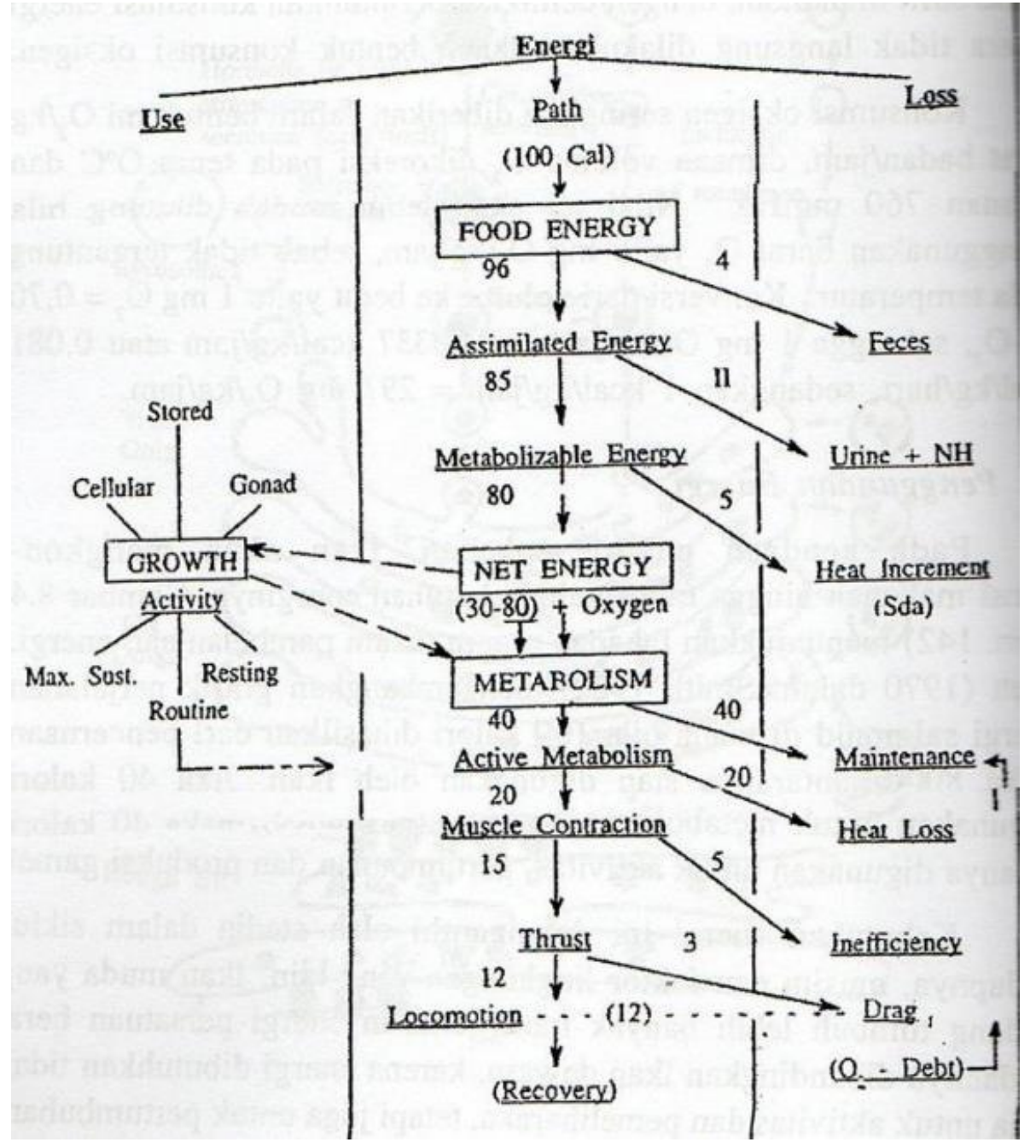

Gambar 3. Ilustrasi tahapan penggunaan energi (Brett 1970)

Derajat keasaman $(\mathrm{pH})$ suatu perairan mencirikan ekspresi dari konsentrasi ion $\mathrm{H}+$ yaitu keseimbangan antara asam dan basa (Saeni 1989). Derajat Keasaman $(\mathrm{pH})$ tersebut berpengaruh terhadap aktivitas enzim-enzim yang bekerja pada organ insang misalnya ATP-ase, karbonie anhidrase dan $\mathrm{Na}+\mathrm{K}+\mathrm{ATP}-$ ase. Aktivitas enzim pada insang berkaitan dengan laju respirasi, osmoregulasi dan ekskresi (Affandi dan Tang 2002). Nilai $\mathrm{pH}$ yang rendah ( $\mathrm{pH}$ asam) pada perairan dapat berdampak terhadap menurunnya laju konsumsi oksigen, sebaliknya jika nilai $\mathrm{pH}$ tinggi $(\mathrm{pH}$ basa), maka akan terjadi peningkatan kadar NH3 yang tidak terionisasi yang bersifat toksik bagi kehidupan ikan. Nilai pH tergantung pada beberapa faktor yakni faktor fisika (kekeruhan), kimia (kadar CO2, salinitas) dan biologis (perombakan bahan organik dan densitas organisme). Pada kolam dengan padat penebaran cukup tinggi, nilai $\mathrm{PH}$ cenderung mengalami 
penurunan. Hal tersebut disebabkan oleh tingginya kadar amonia yang bersifat asam. Untuk menanggulangi hal tersebut, petani ikan dapat melakukan langkah antisipasi dengan cara melakukan pergantian air, atau dengan menguraikan amonia pada kolam melalui berbagai teknologi, misalnya bioflok atau probiotik.

Boyd (1982) menyatakan bahwa amonia (NH3) merupaknan racun pada perairan yang dapat menyebabkan terjadinya kerusakan insang dan menurunkan kemampuan darah dalam mengangkut oksigen. Konsentrasi amonia yang sangat tinggi dalam perairan dapat mengakibatkan penurunan ekskresi amonia dari dalam tubuh sehingga akan terjadi akumulasi di dalam darah dan insang. Akumulasi amonia tersebut dapat menyebabkan kemampuan darah dalam mentransportasikan oksigen menjadi berkurang. Berdasarkan Sawyer \& Mc Carty (1978) dalam Effendi (2003) bahwa kadar amonia bebas yang tidak terionisasi (NH3) pada perairan tawar sebaiknya tidak lebih dari 0,2 mg.L-1. Jika kadar amonia bebas lebih dari 0,2 $\mathrm{mg} / \mathrm{L}$, perairan dapat bersifat toksik bagi beberapa jenis ikan. Toksik tersebut dapat masuk ke dalam organisme dapat lewat pernafasan atau permukaan tubuh kemudian memasuki sirkulasi darah (Soemirat 2003). Keberadaan amonia dalam kolam ikan dapat disebabkan oleh sisa pakan yang tidak termakan. Sumber lain adalah eksresi amonia oleh insang ikan. Para petani ikan disarankan untuk mengecek kadar amonia secara teratur menggunakan kyt amonia. Apabila kadarnya sudah mendekati ambang batas, maka dapat dilakukan langkah antisipasi dengan cara pergantian air. Selain itu, pemberian pakan juga harus diperhatikan. Tidak boleh memberikan pakan yang berlebihan sehingga berpeluang menimbulkan amonia.

Salinitas adalah kadar garam seluruh zat yang larut dalam 1.000 gram air laut, dengan asumsi bahwa seluruh karbonat telah diubah menjadi oksida, semua brom dan lod diganti dengan khlor yang setara dan semua zat organik menga1ami oksidasi sempuma (Forch et al,1902 dalam Sverdrup et al, 1942). Salinitas mempunyai peran penting dan memiliki ikatan erat dengan kehidupan organisme perairan termasuk ikan. Salinitas juga berhubungan dengan pertumbuhan sebagaimana penelitian yang dilakukan oleh Scabra (2013), bahwa salinitas yang berbeda yang diaplikasikan pada media budidaya udang vannamei juga memberikan efek pertumbuhan yang berbeda pula. Hal tersebut dikuatkan kembali dengan peelitian serupa oleh Scabra (2016), bahwa perbedaan tekanan osmotik pada media yang disebabkan oleh perbedaan salinitas memberikan pengaruh yang berbeda terhadap pertumbuhan ikan sidat. 


\section{KESIMPULAN DAN SARAN}

Kesimpulan pelaksanaan
kegiatan pengabdian kepada
masyarakat ini antara lain:
1. Terjalinnya hubungan
silaturrahmi antara masyarakat
dengan para akademisi
2. Meningkatnya wawasan
masyarakat tentang budidaa
ikan air tawar
3. Menambah pengalaman dosen
dalam menyalurkan ilmu
kepada para petani

\section{DAFTAR PUSTAKA}

Affandi R, Tang M. 2002. Fisiologi Hewan Air. Jakarta (ID): Unri Press.

Boyd CE, 1982. Water Quality Management in Pond Fish Culture. New York (US): Elsevier Scientific Publishing Company.

Effendi H. 2003. Telaah Kualitas Air bagi Pengelolaan Sumberdaya dan Lingkungan Perairan. Yogyakarta (ID): Kanisius.

Harianto E. 2014. Kinerja produksi ikan sidat Anguilla marmorata ukuran 7 gram dengan kepadatan tinggi pada sistem resirkulasi melalui kajian fisiologis [tesis]. Bogor (ID): Institut Pertanian Bogor.

Saeni MS. 1989. Kimia Lingkungan. Bogor (ID): Institut Pertanian Bogor.

Scabra AS. 2013. Pemberian Jenis Pakan Yang Berbeda pada pemeliharaan udang vannamei dengan media bersalinitas rendah (skripsi). Malang (ID): Universitas Muhammadiyah Malang.

Scabra AS. 2015. Kinerja produksi ikan sidat anguilla bicolor bicolor berukuran awal $10 \mathrm{~g} /$ ekor pada media budidaya dengan salinitas dan kalsium karbonat (CaCo3) yang berbeda (tesis). Bogor (ID): Institut Pertanian Bogor.

Scabra AS. 2016. Kinerja produksi ikan sidat (Anguilla bicolor) berukuran 10 gram dengan pemberian kalsium karbonat (caco3) pada media budidaya. Jurnal Akuakultur Indonesia, 15:1.

Soemirat, J. (2003). Toksikologi Lingkungan. Yogyakarta (ID): Gadjah Mada University Press. 